\title{
Sermones varii. \\ Kazania w średniowiecznych rękopisach ze zbiorów Archiwum Polskiej Prowincji Dominikanów w Krakowie jako świadectwo praktyki kaznodziejskiej polskich dominikanów
}

Sermones varii, sformułowanie, które znalazło się w tytule tego artykułu, jest zmorą wszystkich badaczy średniowiecznych kazań. Pojawia się on bardzo często w inwentarzach i katalogach nieroszczących sobie pretensji do dokładności. Opracowujący takie katalogi i inwentarze, zwłaszcza przytłoczeni liczbą kazań i kłopotami związanymi $\mathrm{z}$ ich identyfikacja, zwykli używać uniku, określając znalezione w rękopisach kazania jednym zbiorczym tytułem: sermones varii. Nie inaczej było w przypadku zbioru rękopisów dominikańskich z Archiwum Polskiej Prowincji Dominikanów w Krakowie. Do czasu opracowania szczegółowego katalogu tych kodeksów wiedzieliśmy niewiele ponad to, że zawierają one kazania. Zofii Włodek, która opracowała inwentarz tej kolekcji - przez lata podstawowy przewodnik po rękopisach krakowskich dominikanów - udało się zidentyfikować zaledwie niewielką część tekstów kaznodziejskich ${ }^{1}$. Prace nad wspomnianym katalogiem, prowadzone pod kierunkiem piszącej te słowa w latach 2011-2014, zmieniły ten stan rzeczy².

Zbiór rękopisów średniowiecznych przechowywanych w krakowskim archiwum obejmuje 59 rękopisów (jeśli za granicę średniowiecza uznamy, jak to uczyniono, opracowując katalog, Sobór Trydencki). Ponad połowę kolekcji stanowią rękopisy liturgiczne (34 kodeksy), druga

1 Z. Włodek, Inventaire des manuscrits médiévaux latins, philosophiques et théologiques de la bibliothèque des pères dominicains de Cracovie, „Mediaevalia Philosophica Polonorum" 14:1970, s. 155-186.

2 Zgodnie z planem katalog ma się ukazać drukiem w 2017 r. 
część to czternasto- i piętnastowieczne kodeksy filozoficzno-teologiczne (25 rękopisów). Największym wyzwaniem w przypadku tych drugich jest ustalenie ich proweniencji. Tylko w przypadku nielicznych jest ona niepodważalna, w wielu hipotetyczna a w części niemożliwa do ustalenia. Trafiły one do klasztoru krakowskiego po drugiej wojnie światowej a pochodziły z dwóch źródeł: z klasztorów dominikańskich we Lwowie oraz w Raciborzu. Wśród tych drugich znalazły się także kodeksy kapituły w Raciborzu, które w nieznanym momencie dziejów przeszły na własność dominikanów. Na owe 25 kodeksów filozoficznoteologicznych aż 18 zawiera kazania. Rękopisy te można podzielić na trzy grupy:

1. zawierające spójne, to jest pozostające w porządku liturgicznym kolekcje kazań - dziewięć kodeksów ${ }^{3}$ : XV 15 (MSPL 00045), XV 16 (MSPL 00046), XV 22 (MSPL 00052), XV 24 (MSPL 00054), XV 26 (MSPL 00056), XV 27 (MSPL 00057), XV 32 (MSPL 00062), XV 34 (MSPL 00064), XV 36 (MSPL 00066);

2. w całości wypełnione kazaniami, które jednak nie tworzą spójnej kolekcji - dwa kodeksy: XV 28 (MSPL 00058), XV 33 (MSPL 00063);

3. w których kazania występują obok innych gatunków tekstów siedem kodeksów: XV 2 (MSPL 00034), XV 6 (MSPL 00037), XV 8 (MSPL 00038), XV 9 (MSPL 00039), XV 11 (MSPL 00041), XV 13 (MSPL 00043), XV 29 (MSPL 00059).

W tej ostatniej grupie możemy wyodrębnić rękopisy, w których pojedyncze kazania tworzą cykle dobrane według określonego klucza (liturgicznego, tematycznego, posiadające tę samą grupę adresatów) oraz te, które takich grup nie tworzą.

Osobną klasyfikację można przeprowadzić, biorąc pod uwagę autorstwo kazań: na jedenaście kodeksów w całości wypełnionych kazaniami pięć zawiera kazania znanych autorów, sześć zaś autorów anonimowych (XV 15, 16, 28, 32, 33, 34). Siedem kodeksów z kazaniami poza kolekcjami bądź tworzącymi mniejsze kolekcje tematyczne zawiera łącznie 325 tekstów; z tego 135 to kazania autorskie bądź takie, które notowane są w innych repertoriach; zaledwie trzy kazania mają za autorów znanych polskich dominikanów. Pozostałe 187 kazań to teksty anonimowe.

3 W sygnaturach rękopisów pominięte zostają poprzedzające je litery „R” lub „L”, które według zamysłu je nadających miały określać proweniencję kodeksów. Prowadzone na potrzeby katalogu badania pokazały, że były one błędnie przypisywane. Numery MSPL odsyłają do opisów na portalu Manuscripta.pl <http://manuscripta.pl/>. 
Co nam te wszystkie liczby i zestawienia mówią. Po co w ogóle je sporządzać? Czy jest to tylko spełnienie inwetaryzacyjnego obowiązku, czy też próba całościowego spojrzenia na rękopisy kaznodziejskie, która pozwala nam dojść do jakichś bardziej uniwersalnych wniosków?

W toku badań nad średniowiecznym kaznodziejstwem mediewiści proponowali różne podejścia do tekstów kazań. Widziano w nich teksty literackie, traktaty teologiczne, źródła do badań nad mentalnością i życiem codziennym itd. Wszystkie te ujęcia są jak najbardziej uprawnio$n^{4}$. W niniejszym tekście chcielibyśmy jednak spojrzeć na rękopiśmienne teksty kazań przede wszystkim jako na świadectwa średniowiecznej praktyki kaznodziejskiej.

Patrząc $\mathrm{w}$ ten sposób na krakowskie rękopisy dominikańskie, postaramy się - choć w bardzo ograniczonym zakresie - odpowiedzieć na postulat zgłaszany przez Jerzego Wolnego $\mathrm{w}$ jego pionierskim artykule o kaznodziejstwie dominikańskim w Polsce średniowiecznej ${ }^{5}$. Autor ten zwrócił uwagę na fakt, że ,rozwinięcie działalności kaznodziejskiej-czy to przez księży parafialnych, czy przez zakonników - było niewątpliwie uzależnione od posiadania zbiorów kazań, zbiorów hagiograficznych, komentarzy do Pisma św., samego tekstu Pisma św., różnych słowników itp. O rozwoju kaznodziejstwa decydowało więc nie tylko samo wykształcenie teologiczne kaznodziejów, ale przede wszystkim posiadanie odpowiednich ksiag"”. Na tę zależność miedzy zasobnością biblioteki a działalnością kaznodziejską wskazywał też Jan Długosz w cytowanym przez Wolnego fragmencie Roczników: „odtąd nauka się rozkrzewiła i książki zagościły, a kazania polskie zaczęły rozbrzmiewać nie tylko po miastach - lecz i po wsiach całego królestwa"7. W dalszej części wywodu Wolny wyciaga konkluzję z powyższych stwierdzeń, postulując: „Powstaje więc pytanie, jakie zbiory kazań, zbiory hagiograficzne i inne pomoce kaznodziejskie były znane i używane przez polskich kaznodziejów dominikańskich"8. Sam na

${ }^{4}$ Kazania i forma ich transmisji mają bardzo bogatą literaturę, której nie sposób tu wymienić. Za podstawową pracę omawiająca kazania jako gatunek literackich uchodzi The sermon, ed. B. M. Kienzle, Tournhout 2000 (Typologie des Sources du Moyen Âge Occidental, 81-83). Ostatnio badania nad kaznodziejstwem, przeprowadzone już po ukazaniu się The Sermon, podsumowała Anne T. Thayer w artykule Medieval Sermon Studies since ,, The Sermon”: A Deepening and Broadening Field, „Medieval Sermon Studies", 58:2014, s. 10-27.

J. Wolny, Uwagi o kaznodziejstwie dominikańskim w Polsce średniowiecznej, [w:] Studia nad historia dominikanów w Polsce. 1222-1972, red. J. Kłoczowski, t. 1, Warszawa 1975, s. 543-551.

6 Tenże, Uwagi..., s. 546.

7 Cyt. za J. Wolny, Uwagi..., s. 546.

8 J. Wolny, Uwagi..., s. 546. 
to pytanie jednak nie udzielił odpowiedzi, ograniczając się do kilku uwag na temat zbioru kazań Peregryna z Opola. Postaramy się to uczynić w niniejszym tekście, zawężając krąg swoich poszukiwań do zbioru krakowskiego. Paradoksalnie jego zaletą może być jego przypadkowość - daje on nam w pewnym sensie losową próbę kodeksów przechowywanych w dominikańskich bibliotekach, co może dawać nadzieję, że wnioski wyciagane na jego podstawie mogą być w jakimś stopniu reprezentatywne dla bibliotek dominikańskich w ogóle. Wyniki analizy zbioru krakowskiego powinny zostać jednak zweryfikowane przez porównanie ze śląskimi bibliotekami dominikańskimi, stanowiącymi, jak powszechnie wiadomo, największy zbiór dominikańskich rękopisów średniowiecznych polskiej prowincji. Przeprowadzenie takich gruntownych badań, jeśli nie uniemożliwia, to znacznie utrudnia brak nowoczesnego katalogu rękopisów Biblioteki Uniwersyteckiej we Wrocławiu, którego opracowanie badacze dominikańskiej kultury intelektualnej postulują bezskutecznie od lat.

$\mathrm{Na}$ początku rozważań na temat rękopisów kaznodziejskich trzeba stwierdzić rzecz tyle oczywista, co często przez badaczy pomijaną. Kazania były w pierwszym rzędzie tekstami przeznaczonymi do wygłaszania. Ich forma pisana - choć nierzadko pierwsza chronologicznie - jest wtórna wobec żywego słowa, jakie padało z ambony. Kazania były spisywane po to, by mogły być później wygłaszane. W średniowiecznych rękopisach mamy do czynienia zatem bądź ze zbiorami kazań modelowych, tworzonych jako pomoc dla kaznodziejów w układaniu własnych kazań, bądź z reportacjami, a więc notatkami sporządzanymi przez słuchaczy w czasie trwania kazania, nierzadko poddawanymi później autoryzacji i stanowiącymi podstawę nowych kolekcji kazań modelowych, bądź z notatkami kaznodziei - kopiami przeczytanych bądź zasłyszanych kazań, a także szkicami własnych homilii, gromadzonymi i opracowywanymi z myślą o własnej praktyce kaznodziejskiej

Co do tego, że kazania w średniowieczu były głoszone, rozmaite przekazy źródłowe (historiografia, hagiografia, akty normatywne) nie pozostawiają wątpliwości. O wiele większy kłopot mamy z ustaleniem, co głoszono. Słowo mówione bezpowrotnie zginęło w mrokach dziejów, a wymienione kategorie źródeł zazwyczaj na ten temat milczą (skrajnym przykładem jest tu działalność kaznodziejska Jana Kapistrana w czasie pobytu w Krakowie: Długosz zdaje szczegółową relację z tego kiedy, gdzie, jak i do kogo Kapistran kazał, nie wspominając przy tym ani słowem, co mówił ${ }^{9}$ ). Mając

9 Joannis Dlugossii Annales seu Cronicae incliti Regni Poloniae, lib. XII, ed. D. Turkowska, red. J. Wyrozumski, opr. K. Ożóg, Cracoviae 2003, s. 171. Ostatnio źródła historiograficzne dotyczące kaznodziejskiej działalności Jana Kapistrana w Krakowie 
to na uwadze, powinniśmy patrzeć na teksty kazań zachowane w rękopisach przede wszystkim jako na źródła pozwalające nam uzupełnić tę lukę pozostawioną przez inne typy przekazów. Pamiętać przy tym oczywiście należy, że zachowane teksty kazań - bez względu na to, czy mamy do czynienia z reportacjami, czy kazaniami modelowymi - nigdy nie sa wiernym zapisem realnie wygłoszonego tekstu. Pozostają jednak najbliższe temu, co rozbrzmiewało ze średniowiecznych ambon. Więcej - nierzadko kodeksy kaznodziejskie pozwalają nam ustalić nie tylko, co, ale i kto, kiedy oraz do kogo głosił. Jest to możliwe dzięki rozmaitym notom marginalnym, kolofonom, glosom czy zwrotom do słuchaczy zawartym w tekstach.

Co zatem o praktyce kaznodziejskiej dominikanów polskiej prowincji mówią nam rękopisy kaznodziejskie ze zbiorów krakowskiego archiwum? Poważne wyzwanie w badaniach na tym księgozbiorem stanowi dla nas ustalenie proweniencji poszczególnych kodeksów. Co do części, także spośród tych zawierających kazania, jesteśmy przekonani, że nie zawsze były własnością dominikańską. Niektóre w jakimś momencie swoich dziejów należały do kolegiaty w Raciborzu (zawierające kazania sygn.: XV 34, 35 i 36), a z kolei kodeks XV 16, według opracowującej ten kodeks na potrzeby katalogu Dagmary Wójcik-Zegi, najprawdopodobniej należał do jakiegoś konwentu franciszkańskiego. Dla szeregu innych rękopisów nie jesteśmy w stanie ustalić jakiejkolwiek proweniencji (sygn.: XV 13, 22, 27, 28 i 33). Wszystkie one jednak zostały uwzględnione w poniższej analizie, gdyż, nie znając szczegółowo ich historii, nie możemy wykluczyć, że były własnością dominikanów już w średniowieczu.

Tym sposobem przedmiotem rozważań będzie osiemnaście kodeksów, z których jedenaście zawiera kolekcje kazań (sygn.: XV 15, 16, 22, 24, $26,27,28,32,33,34,36)$ a siedem - teksty pozostające poza takimi kolekcjami (sygn.: XV 2, 6, 8, 9, 11, 13, 29). Jeśli chodzi o chronologię, to w grupie tej znalazł się jeden kodeks XIV-wieczny (sygn. XV 9), cztery z samego poczattku XV w. (sygn.: XV 11, 15, 22, 28), osiem z pierwszej połowy XV w. (sygn.: XV 24, 26, 28, 29, 8, 6, 27, 13) oraz sześć z lat 70. XV stulecia (sygn.: XV 2, 16, 32, 33, 34, 36).

zestawił i przenalizował Piotr Kołpak (Ambona Krakowa. Tradycja kaznodziejska elementem sakralizacji przestrzeni krakowskiego Rynku w świetle wybranych źródet, [w:] Signa. Studia i szkice z nauk pomocniczych historii. Prace dedykowane Profesorowi Zenonowi Piechowi w sześćdziesiata rocznicę urodzin, red. A. Marzec, M. Starzyński, Kraków 2014 (Studenckie Zeszyty Historyczne Koła Naukowego Historyków Studentów UJ, z. 21), s. 152-155. 


\begin{tabular}{|l|l|}
\hline Rekopis & Datacja \\
\hline XV 9 & $1340-1375$ \\
\hline XV 11 & ok. 1400 \\
\hline XV 15 & ok. 1400 \\
\hline XV 22 & 1400 \\
\hline XV 28 & 1419 \\
\hline XV 24 & drugie dziesiecciolecie XV W. \\
\hline XV 26 & $1420-1425$ \\
\hline XV 8 & $1429-1434$ \\
\hline XV 6 & $1430-1450$ \\
\hline XV 27 13 & 1440 \\
\hline XV 2 & 1443 \\
\hline XV 32 33 & 1450 \\
\hline XV 16 & 1470 \\
\hline XV 36 & 1470 \\
\hline XV 34 & 1470 \\
\hline & 1472 \\
\hline & 1472 \\
\hline
\end{tabular}

Co ta relatywnie pokaźna grupa tekstów mówi nam o praktyce kaznodziejskiej polskich dominikanów u schyłku XIV i w XV wieku?

\section{Czy głoszono?}

Wypada zacząć od pytania, czy rękopisy kaznodziejskie, które znajdujemy w Archiwum Polskiej Prowincji Dominikanów w Krakowie pozwala ją nam stwierdzić, że zawarte w nich kazania były głoszone przez polskich dominikanów. Czy noszą jakieś ślady pracy kaznodziejów - osobiste notatki, uzupełnienia? Czy zawierają kolofony bądź noty marginalne wskazujące na okoliczności lub przynajmniej sam fakt wygłaszania tych tekstów?

Odpowiadając na to pytanie, już na wstępie trzeba zaznaczyć, że rękopisy kaznodziejskie z omawianej kolekcji podzielić można przynajmniej na dwie grupy. W jednej znajdą się osobiste rękopisy-notatniki, sporządzane na własny użytek, w drugiej - kodeksy kupowane czy zamawiane na potrzeby wspólnoty. Do pierwszej grupy na pewno trzeba zaliczyć kodeksy XV 6 i 8 . Na podstawie ich zawartości możemy stwierdzić, że są to rękopisy powstałe w związku z działalnością dominikańskich szkół. Zawarte w nich mowy i kazania były wygłaszane bądź w samych szkołach (principia ${ }^{10}$, mowa de beanis ${ }^{11}$ ), bądź do wspólnoty zakonnej (klasztornej, kapituły prowincjonalnej $^{12}$ ) być może $\mathrm{w}$ związku z pełnieniem przez korzystającego $\mathrm{z}$ omawia-

${ }^{10}$ Por. np. rps. XV 6, s. 13-15; 111-118; 127-136.

${ }^{11} \mathrm{Na}$ jej temat zob. A. Zajchowska, Czy w dominikańskim , Studium generale” w Krakowie urzadzano otrzęsiny? „, Collatio de beanis” w rękopisie L XV 6 z Archiwum Polskiej Prowincji Dominikanów w Krakowie, „Przegląd Tomistyczny”, t. 16:2010, s. 59-75

12 Por. np. rps. XV 6, s. 33-39, 41-47. 
nego rękopisu kaznodzieję funkcji lektora konwentu (kazania o świętych dominikańskich ${ }^{13}$ ). W obu kodeksach znajdziemy imiona autorów (ewentualnie - co wydaje się mniej prawdopodobne - kopistów) niektórych kazań. W przypadku kodeksu XV 6 jest to Mikołaj Falkenberg ${ }^{14}$, a XV 8 Piotr z Kościana ${ }^{15}$, do którego kodeks ten należał i którego ręką w całości został spisany. W przypadku wspomnianych kazań „okolicznościowych” - principiów, kazań z kapituły prowincjonalnej - mamy najpewniej do czynienia $\mathrm{z}$ reportacjami i raczej nie mamy watpliwości, że były one faktycznie wygłoszone. Część kazań z kodeksu Piotra z Kościana (XV 8) to zapewne teksty spisane $\mathrm{z}$ innych zbiorów - trudnych do zidentyfikowania. Upewnia nas o tym kolofon jednego z nich: „Frater Petrus de Costen Ordinis Fratrum Predicatorum existens in persecucione scripsit hec et colegit de diversis etc." ${ }^{\prime 16}$. Możliwe, że czasownik colegit odnosi się nie tyle do zbioru kazań, z których zaczerpnięto całe kazania, co opisuje samą czynność układania utkanych z cytatów kazań. Wtedy musielibyśmy uznać Piotra nie za kopistę, lecz za twórcę kazań.

Większość tekstów kazań, które znajdujemy w kodeksach dominikańskich, zapewne najpierw była układana bądź kopiowana, a dopiero potem wygłaszana. W każdym razie nie mamy żadnych wyraźnych wskazówek pozwalających nam twierdzić inaczej, bo nie towarzyszą im żadne noty wskazujące na fakt ich wcześniejszego wygłoszenia. W pewnym sensie wyjątek stanowią tu dwa kazania, które z całą pewnością - o czym wiemy z innych przekazów źródłowych - były najpierw wygłoszone, a dopiero potem spisane, jednak w momencie ich skopiowania do rękopisów dominikańskich pełniły już de facto rolę kazań modelowych. Mowa tu o dwóch kazaniach z rękopisu XV 33. Znalazło się tam jedno z kazań z soboru w Bazylei ${ }^{17}$ oraz kazanie Jana Frankensteina z katedry wrocławskiej ${ }^{18}$.

Przytłaczająca większość kazań powstała o wiele wcześniej, nim trafiła do dominikańskich rękopisów, i zapewne niejednokrotnie była wykorzy-

13 Rps. XV 6, s. 302-312 (św. Piotr Męczennik); rps. XV 6, s. 286-295 (św. Tomasz z Akwinu).

${ }_{14}$ Rps. XV 6, s. 5-8.

${ }_{15} \mathrm{Na}$ temat Piotra z Kościana i jego udziału w powstaniu rękopisu XV 8 zob. Z. Pajda, Rękopis L.XV.8. Z Archiwum OO. Dominikanów w Krakowie, „Przegląd Tomistyczny", 6-7:1997, s. 443-469.

16 Rps XV 8, k. 94v.

17 Por. rps XV 33, s. 191-205.

18 Zostało one opatrzone nota: ,Sermonem presentem magister Iohannes Franckensteyn sacre theologie professor, frater Ordinis Predicatorum recollegit", rps XV 33, s. 693. Szczegółowe informacje dotyczące tego kazania oraz jego edycja: A. Ledzińska, A. Zajchowska, ,, Mulier nequam” - kazania dominikanina Jana z Zabkowic do kapituły wrocławskiej o celibacie i kapłańskiej czystości, „Studia Źródłoznawcze”, 48:2010, s. 59-84. 
stywana jako materiał kaznodziejski na ambonach całej Europy. Kazania te najprawdopodobniej pełniły funkcję modelowych, a więc stanowiły wstępny materiał wykorzystywany w czasie głoszenia ${ }^{19}$. Jest to oczywiste w przypadku znanych kolekcji tego typu tekstów, ale dotyczy także kazań rozproszonych wśród innych gatunków tekstów. Świadczą o tym między innymi wskazówki dla kaznodziejów, które w nich znajdujemy, typowe właśnie dla kazań modelowych. Najwięcej ich udało się znaleźć w rękopisie XV 33. Kazanie o Nawiedzeniu Najświętszej Marii Panny kończy się tam słowami: „Dic exemplum”20, a o narodzeniu Maryi: „Dic miraculum et conclude” ${ }^{21}$, z kolei kazanie o św. Janie Ewangeliście: „Hic potes plura addere, si tibi placet, sin autem concludi, ut tibi videbitur expedire" 22 .

Wszystkie analizowane rękopisy noszą ślady lektury - manikula, noty treściowe, podkreślona struktura tekstu etc. Wyjątkowo intensywnie czytane i opracowywane były dwa kodeksy: XV 26 i XV 32. W rękopisie XV 26, jak ustaliła to autorka opisu tego kodeksu Dagmara Wójcik-Zega - znalazły się noty przynajmniej dwóch, a być może trzech pisarzyczytelników. Pierwszy uzupełniał kazania Hieronima o obszerne wypisy z kazań Peregryna z Opola, Cateny św. Tomasza z Akwinu i innych niezidentyfikowanych źródeł; drugi wprowadził glosy interlinearne i marginalne będące objaśnieniem trudnych słów, często wraz z polskim ich thumaczeniem. Podobny charakter mają glosy w rękopisie XV 32. Poza objaśnieniami słów i polskimi glosami leksykalnymi znajdziemy tam również rozważania dotyczące głównego tekstu kazania (np. tam, gdzie mowa o odnalezieniu Jezusa w świątyni, pojawia się na marginesie pytanie: ,po co rodzice wzięli ze sobą Jezusa do Jerozolimy?”23).

\section{Co głoszono?}

Wśród autorów kolekcji kazań modelowych przechowywanych w archiwum krakowskim znaleźli się: Jakub z Voraginy (XV 22), Jan de Sancto Gimignano (XV 24), Jan Silvanus z Pragi (XV 26), Tomasz Ebendorfer (XV 27) i Piotr Meffordis (XV 36). Dwa pierwsze kodeksy zawierają kolekcje autorów dominikańskich tworzących u schyłku wieku XIII i na początku XIV powszechnie używane w całej Europie. Ko-

\footnotetext{
${ }_{19} \mathrm{Na}$ temat kazań modelowych zob. np. D. d'Avray, Preaching of the Friars. Sermones Defused from Paris before 1300, Oxford 1985, s. 105.

${ }^{20}$ Rps XV 33, s. 245.

21 Rps XV 33, s. 294.

22 Rps XV 33, s. 448.

23 Por. XV 32, k. 24r.
} 
lekcja kazań wielkopostnych Jana z San Gimignano należy z kolei do najczęściej kopiowanych i drukowanych (jeszcze w XVII wieku!) kazań tego włoskiego dominikanina żyjącego na przełomie XIII i XIV stulecia (zm. 1333) ${ }^{24}$. Do tej listy kolekcji dominikańskich należy jeszcze dodać zbiór kazań Peregryna z Opola. W zbiorach krakowskich nie zachował się żaden rękopis z pełną kolekcją kazań tego autora, ale bez wątpienia teksty polskiego dominikanina z przełomu XIII wieku były jego współbraciom dobrze znane, bo wśród kazań nietworzących spójnej kolekcji te autorstwa Peregryna stanowią przytłaczającą większość. Wypisy z nich znajdziemy też na marginesach wspomnianej już kolekcji Jana Hieronima z Pragi ${ }^{25}$. O ile inni autorzy reprezentowani sa przez maksymalnie pięć tekstów, a zazwyczaj jeden, to w dominikańskich rękopisach mamy kolekcję kilkudziesięciu kazań Peregryna, należących zarówno do kolekcji de tempore ${ }^{26}$, jak i de sanctis ${ }^{27}$. Jeśli do Peregryna dodamy jeszcze fragment Postylli Mikołaja z Liry z rękopisu XV $9^{28}$, to okaże się, że w wyborze kolekcji kazań, które stanowiły materiał wyjściowy do układania kazań głoszonych do wiernych (wszystkie wymienione kolekcje, to kolekcje kazań ad populum), polscy dominikanie byli bardzo zachowawczy, wykorzystując jeszcze w drugiej połowie XV wieku kolekcje z XIII i początku XIV w.

Z tego schematu wyłamują się trzy piętnastowieczne kolekcje kazań: Jana Hieronima z Pragi, Thomasa Ebendorfera i Piotra Meffordis. Linea salutis - zbiór kazań niedzielnych na cały rok - to jedna $\mathrm{z}$ dwóch kolekcji pióra Jana Hieronima z Pragi, spowiednika i kaznodziei Władysława Jagiełły, napisanych na prośbę polskich duchownych ${ }^{29}$. Jan Hieronim był wpływowa postacią na dworze Jagiełł, jednym z jego najbliższych doradców, podróżującym wraz z dworem po całym państwie, a zarazem członkiem Uniwersytetu Krakowskiego ${ }^{30}$. Sam Długosz wypowiadał się na temat Linea salutis, chwaląc ją za jasność i zwięzłość stylu ${ }^{31}$. W prologu do kolekcji pięćdziesięciu czterech kazań Hieronim podkreślał, że

${ }^{24} \mathrm{Na}$ temat Jana $\mathrm{z}$ San Gimignano i jego zbiorów kaznodziejskich zob. A. Dondaine, La vie et les oeuvres de Jean de San Gimignano, „Archivum Fratrum Praedicatorum” 9:1939, s. 128-183; na temat zbioru i jego tradycji rękopiśmiennej s. 143-148.

${ }_{25}$ Por. np. rps XV 26, s. 39, 53, 110, 111.

26 Rps XV 9, s. 301-302; rps XV 11, s. 97-108, 146-153, 176-179, rps XV 32, k. $234 \mathrm{r}-235 \mathrm{r}$.

${ }^{27}$ Rps XV 28, k. 75r-134v; XV 32, k. 235v-236r; XV 33, s. 461-465.

${ }_{28}$ Rps XV 9, s. 2-64,72-75, 242-289.

29 W. Hyland, Abbot John-Jerome of Prague. Preaching and Reform in Early Fifteenth-Century Poland, ,, Analecta Praemonstratensia”, 80:2004, s. 5.

30 Tamże, s. 6-7.

31 Tamże, s. 9. 
napisał je, by spełnić swój obowiązek upominania grzeszących bliźnich, przypominając jednocześnie, że ten sam obowiązek spoczywa na wszystkich duchownych ${ }^{32}$. W tym samym prologu występuje on $\mathrm{z}$ tradycyjna krytyką nadużyć duchowieństwa zaniedbującego duszpasterskie obowiązki, co - wraz z wieloma innymi jego pismami - umieszcza go w gronie kościelnych reformatorów XV w. Same kazania, pisane prostą łaciną i w zasadniczej części czerpiące z zastanej tradycji egzegetycznej, maja być pomoca dla duchowieństwa $\mathrm{w}$ spełnianiu nałożonego na nich obowiązku głoszenia Słowa ${ }^{33}$. Thomas Ebendorfer to z kolei piętnastowieczny koncyliarysta, a zarazem gorliwy oponent husytyzmu ${ }^{34}$, Piotr Meffordis zaś, autor kazań ad populum, starał się łączyć krytykę współczesnego mu stanu Kościoła z obroną jego instytucji i nauczania ${ }^{35}$.

Do zbiorów kazań o znanym autorstwie należy dołączyć teksty anonimowe. Kazania anonimowe, które nie są znane z żadnych innych rękopisów, stanowią ponad połowę wszystkich tekstów kaznodziejskich, jakie znajdujemy w dominikańskich kodeksach. Jak zawsze w przypadku kazań anonimowych stajemy przed pytaniem, czy pisarz rękopisu był ich kopista, czy autorem ${ }^{36}$. I dalej, jeśli uznamy, że mamy przed sobą kopie kazań, to nadal musimy zmierzyć się z problemem, kto był autorem pierwowzoru. Dla nas szczególnie ważna jest kwestia, czy były one autorskimi - w dzisiejszym tego słowa znaczeniu - dziełami polskich dominikanów, czy też kopiami, kompilacjami bądź przeróbkami tekstów powstałych poza środowiskiem polskiej prowincji. Odpowiedź może przynieść jedynie gruntowna analiza tych kazań, na którą rzecz jasna nie ma tu miejsca.

Nie będziemy się też w tym miejscu szczegółowo zajmować treścią głoszonych kazań, bo jest to zadanie dalece wykraczające poza ramy tego artykułu. Prowadzone dotąd badania nad kaznodziejstwem dominikańskim pokazują, że było ono raczej konserwatywne. Bracia niechętnie poruszali bieżące tematy, budzące największe kontrowersje w Kościele

${ }^{32}$ Tamże, s. 11.

33 Tamże, s. 18.

$34 \mathrm{Na}$ jego temat zob. A. Lhotsky, Thomas Ebendorfer. Ein österreichischer Geschichtsschreiber, Theologe und Diplomat des 15. Jahrhunderts, Stuttgart 1957 (Schriften der Monumenta Germaniae historica, 15).

$35 \mathrm{Na}$ temat Piotra i jego twórczości zob. D. Schmidtke, Die deutsche Literatur des Mittelalters: Verfasserlexikon, ed. K. Ruh i in. V. 6, Berlin 1987, s. 297-300.

$36 \mathrm{Na}$ temat różnych koncepcji średniowiecznego autorstwa zob. A. Zajchowska, Quattuor est modus faciendi librum. Kazania ad clerum z rękopisu BUWr I Q 377 w świetle średniowiecznej teorii autorstwa, [w:] Przestrzeń religijna Europy ŚrodkowoWschodniej w średniowieczu / Religious Space of East-Central Europe in the Middle Ages, pod red. K. Brachy i P. Krasa, Warszawa 2010, s. 281-306. 
(spór o Eucharystię wywołany przez husytów, elementy nowej etyki ekonomicznej czy spory eklezjologiczne) $)^{37}$.

\section{Kiedy głoszono?}

Zbiory kazań przechowywane w dominikańskich bibliotekach pozwalają nam też wyciagać ostrożne wnioski na temat okoliczności głoszenia kazań. Herve Martin, badając praktykę kaznodziejską w późnośredniowiecznej Francji przede wszystkim na podstawie kronik i rachunków miejskich, zauważył, że na 1147 wzmianek o głoszeniu kazań zaledwie 262 podaje precyzyjne informacje o czasie ich głoszenia ${ }^{38}$. Te wyrywkowe informacje pokrywają się jednak z danymi, jakich dostarczają nam kaznodziejskie rękopisy, co czyni oba typy źródeł wiarygodnymi świadkami praktyki kaznodziejskiej.

$\mathrm{Z}$ badań francuskiego uczonego wynika, że o ile regularne kaznodziejstwo w parafiach ograniczało się co najwyżej do krótkich homilii w czasie mszy czy odczytania statutów synodalnych, to klasztory mendykanckie w miastach były ośrodkami regularnego głoszenia kazań niedzielnych i świątecznych ${ }^{39}$. Za świadectwo tej działalności dominikanów polskiej prowincji uznać można kolekcje kazań modelowych zawierające cały cykl roku liturgicznego.

Grupy kazań nietworzące całego cyklu liturgicznego pozwalają nam przypuszczać, że pewne okresy liturgiczne były szczególnie uprzywilejowane. Do takich okresów należał na pewno Wielki Post oraz Wielkanoc. Kazania wielkopostne znalazły się w rękopisach XV 24 (Quadragesimale Jana z San Gimignano), XV 28 (104 kazania), a także w rękopisie XV 34 (Meditationes de passione Iesu Christi) ${ }^{40}$. Dużą grupę kazań wielkanocnych znajdujemy zaś w kodeksie rękopisu XV 9 (52 kazania). Szczególne miejsce wśród tekstów przeznaczonych na okres paschalny zajmują kazania na Zesłanie Ducha Świętego (kodeksy XV 6, XV 9, XV 33 - dwanaście kazań). Liczną grupę stanowią kazania na święta maryjne

37 Zob. np. A. Zajchowska, Herezja $i$ heretycy $w$ kazaniach dominikanina Jana z Zabkowic (zm. 1446), [w:] Św. Jacek Odroważ i dominikanie na Ślasku, red. A. Barciak, Katowice 2008, s. 172-184; taż, Zagadnienia ekonomiczne $w$ zbiorach kazań modelowych z dominikańskich bibliotek klasztornych w późnym średniowieczu, [w:] Klasztor w gospodarce średniowiecznej i nowożytnej, red. M. Derwich, Wrocław 2013, s. 49-70.

38 H. Martin, Le Métier de Prédicateur en France Septentrionale à la fin du Moyen Âge (1350-1520), Paris 1988, s. 550.

39 Tamże.

40 Teksty składające się na meditationes przez samego anonimowego autora zostały określone jako sermones. Czy rzeczywiście taką funkcję pełniły, czy też były to teksty przeznaczone do osobistej lektury napisane w formie kazań, trudno na tym etapie badań rozstrzygnąć. 
(XV 6, XV 11, XV 33, dwadzieścia kazań), Pańskie (dwadzieścia jeden kazań - XV 8, 9, XV 33) oraz na Boże Ciało (XV 9, XV 33 -dziesięć kazań). To zestawienie pokrywa się ponownie $\mathrm{z}$ tezami, jakie postawił H. Martin, badając pozakaznodziejskie źródła francuskie. Zauważył on, że mendykanci byli zapraszani do parafii, by głosić tam kazania z okazji najważniejszych świąt kościelnych - maryjnych i Pańskich ${ }^{41}$. Ponadto bracia z zakonów żebraczych wygłaszali w miastach cykle kazań adwentowych i wielkopostnych ${ }^{42}$. Świadectwem tego drugiego typu aktywności kaznodziejskiej mendykantów są liczne zbiory kazań wielkopostnych rozproszone po bibliotekach całej Europy. L. Taylor wskazała, że ponad $30 \%$ badanych przez nią tekstów to właśnie kazania wielkopostne ${ }^{43}$.

Jerzy Wolny w przytaczanym na początku artykule zwracał uwagę na rolę hagiografii w dominikańskim kaznodziejstwie. W zbiorach krakowskich zachował się tylko jeden rękopis zawierający kolekcję de sanctis - XV 16. Jednak kazania o świętych stanowią najliczniejszą grupę tekstów znajdujących się poza kolekcjami (56 kazań - 17\% wszystkich „luźnych” kazań). Kazania te adresowane są zarówno do świeckich, jak i do kleru (rękopis XV 6 i 33). W sumie 56 kazań o świętych znajduje się w pięciu różnych rękopisach, z czego ponad połowa znajduje się w dwóch kodeksach: piętnaście kazań w rękopisie XV 6 i szesnaście w XV 33. Co ciekawe, oba te kodeksy zawieraja głównie kazania ad clerum. Wśród świętych, którym poświęcone kazania trafiły do dominikańskich rękopisów, dominują święci ewangeliczni: apostołowie $^{44}$, ewangeliści ${ }^{45}$, Maria Magdalena ${ }^{46}$, św. Szczepan ${ }^{47}$, a także „rekordzista” wśród świętych, jeśli chodzi o liczbę poświęconych mu kazań - Jan Chrzciciel (siedem kazań ${ }^{48}$ ). Obok nich znaleźli się też ojcowie Kościoła (Ambroży ${ }^{49}$ i Hieronim ${ }^{50}$ - po jednym kazaniu), mę-

41 Tamże.

42 Tamże; L. Taylor, Soldiers of Christ. Preaching in Late Medieval and Reformation France, New York 1992, s. 15.

43 L. Taylor, Soldiers..., s. 17.

44 Św. Jakub - rps XV 6, s. 312-316, 346-352; św. Tomasz - rps XV 11, s. 5-10; św. Bartłomiej - rps XV 11 - s. 33-39; św. Andrzej - rps XV 33, s. 448-455; św. Maciej - rps XV 33, s. 455-460; nawrócenie św. Pawła - rps XV 33, s. 722-729.

${ }_{45}$ Św. Jan - rps XV 6, s. 5-8, 69-72, 269-276; św. Marek - rps XV 6, s. 296-302, XV $11-$ s. 117-118.

46 Rps XV 11, s. 30-33, 112.

47 Rps XV 9, s. 295-298.

48 Rps XV 6, s. 316-324, 343-345, rps XV 33, s. 461-465, 684-693.

49 Rps XV 6, s. 296-302 (kazanie to mogło być głoszone bądź na święto św. Marka Ewangelisty, bądź św. Ambrożego; na samym jego początku czytamy: opera beati Ambrosi vel Marci Ewangeliste fuerunt optima; por. rps XV 16, s. 296).

${ }^{50}$ Rps XV 33, s. 782-788. 
czenniczki pierwszych wieków: Katarzyna (pięć kazań w trzech różnych rękopisach ${ }^{51}$ ), Barbara (cztery kazania, wszystkie z jednego rękopisu $^{52}$ ), Agata ${ }^{53}$ i Łucja ${ }^{54}$ (po jednym kazaniu) oraz św. Marcin (dwa kazania $)^{55}$. Spośród nowych świętych kazań doczekały się dwie święte środkowoeuropejskie: św. Elżbieta ${ }^{56} \mathrm{i}$ św. Jadwiga Śląska ${ }^{57}$ - po jednym kazaniu. Tylko w dwóch kodeksach - XV 6 i XV 8 - znajdujemy natomiast kazania poświęcone świętym dominikańskim - św. Tomaszowi z Akwinu $^{58}$ i św. Piotrowi Męczennikowi ${ }^{59}$, oba skierowane, jak można wywnioskować po zawartych w nich zwrotach do słuchaczy, do zakonnych współbraci. W świetle tego zestawienia dominikanie jawią się jako raczej konserwatywni kaznodzieje skłonni promować własnych, mniej popularnych świętych wyłącznie we własnym gronie.

\section{Do kogo głoszono?}

Zachowane kazania potwierdzają znany nam między innymi $\mathrm{z}$ akt kapituł prowincjalnych fakt, że odbiorcami kazań dominikańskich byli zarówno świeccy, jak i duchowieństwo. Najliczniejsza grupę stanowią oczywiście kazania ad populum (to świeccy byli adresatami kazań układanych na podstawie zbiorów kazań modelowych). W aktach kapituł prowincjalnych znajdziemy liczne nominacje na kaznodziejów Polaków i Niemców. Świadectwem ich działalności są kodeksy XV 15, 16, 32, 33, 34 i 36. W kodeksach XV 15 i XV 32 znajdziemy liczne polskie glosy interlinearne ${ }^{60}$, a w kazania z rękopisu XV 33 wplecione zostały niemieckie terminy (być może są to dawne glosy marginalne wciagnięte do tekstu w czasie kopiowania). Oczywiście otwartą pozostaje kwestia, czy owe zwroty wernakularne są świadectwem rodzimego języka kaznodziei, czy jego słuchaczy. Duchowieństwo było na pewno odbiorcami kazań z rękopisu XV 15, a dominikańscy zakonnicy z rękopisu XV 6 i XV 8.

${ }^{51}$ Rps XV 11, s. 15-20, 57-62; XV 32, k. 242r-243r; XV 33, s. 747-756.

${ }^{52}$ Rps XV 33, s. 205-231.

53 Rps XV 11, s. 43-51.

54 Rps XV 11, s. 1-5.

${ }_{55}$ Rps XV 32, k. 245r-246v; XV 33, s. 861-867.

56 Rps XV 33, s. 844-858.

57 Rps XV 33, s. 828-833.

58 Rps XV 6, s. 286-295.

59 Rps XV 6, s. 302-312.

${ }^{60}$ Na temat glos z rękopisu XV 32 zob. R. Laskowski, J. Reczek, Glosy polskie rękopisu Sermones de tempore et de sanctis $n r . X V 32$ Biblioteki OO. Dominikanów w Krakowie z drugiej połowy XV wieku, Wrocław-Warszawa-Kraków 1968. 


\section{Podsumowanie}

Analiza dominikańskich rękopisów kaznodziejskich ze zbiorów Archiwum Polskiej Prowincji Dominikanów w Krakowie pokazuje, że praktyka głoszenia Słowa w Polskiej Prowincji nie odbiegała od tej znanej nam $\mathrm{z}$ innych prowincji zakonu. Bracia głosili regularnie kazania niedzielne i świąteczne, wygłaszali cykle kazań wielkopostnych, a na największe uroczystości roku liturgicznego byli najpewniej zapraszani do kościołów parafialnych. Poza kazaniami ad populum, głoszonymi w językach narodowych - po polsku i po niemiecku - nie zaniedbywali także głoszenia ad clerum. Odbiorcami uczonych kazań łacińskich był zapewne kler świecki, a przede wszystkim wspólnota zakonna. Okazją do głoszenia mów i kazań były także wydarzenia związane z funkcjonowaniem dominikańskich szkół różnych stopni. Bracia korzystali ze znanych zbiorów kazań modelowych, sięgając przy tym najczęściej do tych autorstwa swoich współbraci. Nie można wykluczyć, że także sami układali swoje kazania, tworząc własne kolekcje kazań modelowych, ale autorstwo polskich dominikanów można ponad wszelką wątpliwość potwierdzić tylko w przypadku nielicznych kazań ad clerum.

Powyższe ustalenia są oczywiście jedynie wstępem do dalszych badań, które domagają się poszerzonej kwerendy. Powinna ona zostać rozciagnięta zarówno na inne gatunki literatury kaznodziejskiej (zbiory dystynkcji, egzemplów, hagiografię), jak i na inne biblioteki, przede wszystkim tę wrocławską.

\section{Streszczenie}

Sermones varii. Kazania w średniowiecznych rękopisach ze zbiorów Archiwum Polskiej Prowincji Dominikanów w Krakowie jako świadectwo praktyki kaznodziejskiej polskich dominikanów

Kazania od dłuższego czasu przyciagają uwagę mediewistów. Widziano w nich teksty literackie, traktaty teologiczne, źródła do badań nad mentalnością i życiem codziennym etc. Niniejszy tekst jest próbą spojrzenia na rękopiśmienne teksty kazań przede wszystkim jako na świadectwo średniowiecznej praktyki kaznodziejskiej w Polskiej Prowincji Dominikanów w średniowieczu. Podstawę źródłową badań stanowi zbiór średniowiecznych rękopisów przechowywany obecnie w Archiwum Polskiej Prowincji Dominikanów. W oparciu o osiemnaście przechowywanych tam kodeksów zawierających ka- 
zania podjęto próbę odpowiedzi na pytanie, co, kiedy i do kogo głosili polscy Bracia Kaznodzieje.

Słowa kluczowe: dominikanie - kaznodziejstwo - rękopisy - Kraków - średniowiecze.

\section{Summary}

\section{Sermones varii: Sermons in medieval manuscripts of the Dominican Archives in Cracow as evidence of preaching practices of the Polish Dominican friars}

Sermons are of particular interest to medievalists for quite some time now. These texts are examined as literary pieces, theological treatises, sources for the history of the mind, of everyday life, etc. A. Zajchowska attempts to look at them primarily as evidence of medieval preaching practice of the Dominicans who belonged to the Polish Province of the order. Sources for Zajchowska's survey were furnished by the eighteen manuscript volumes of sermons extant at the Provincial Archives of the Dominicans in Cracow. On the basis of these collections she attempts to answer the questions: what, when, and to whom did the friars preach.

Key words: Dominicans - preaching - manuscripts - Cracow - Middle Ages. 